Journal of Qualitative Criminal Justice \& Criminology

\title{
Book Review | Gender and Policing: Sex, Power, and Police Culture
}

Maria D.H. Koeppel ${ }^{1}$

${ }^{1}$ Sam Houston State University

Published on: Apr 01, 2013

DOI: $10.21428 / 88 d e 04 a 1.5840 b 3 c 9$

License: Creative Commons Attribution 4.0 International License (CC-BY 4.0). 
Louise Westmarland. Gender and Policing: Sex, Power, and Police Culture. Routledge, 2011; 208 pp.; ISBN: 9780415627665.

Originally released in 2001, Louise Westmarland's Gender and Policing has been released with a new publisher. With Routledge's rerelease of the book, it is necessary to reassess the value of its research in the field of gender and policing to determine if it is still relevant. Throughout the book, Westmarland uses qualitative data to explore gendered themes in United Kingdom police forces. More specifically, her work focuses on whether differential deployment exists in policing based on gender and explores the role of gender within policing culture in several different situations. To analyze possible gendered patterns, Westmarland bases her work on two case studies: One on a rural police force of about 1,300 officers, and one on a metropolitan police force of about 3,000 officers. In addition to the six months of ride-alongs and participant observations in each force, the author conducted in-depth interviews with over 35 officers and focus groups with an additional 35 officers.

Westmarland uses the rich data she collected to explore a number of gendered themes in policing including police roles and assignments, a strong theme that was consistent throughout the book. Framed in the concept of differential deployment, Westmarland spends the majority of the book discussing specific policing units such as sex crimes and family protection units to determine the validity of gendered stereotypes in policing, specifically pertaining to promotion. In an effort to examine the stereotype that women are deployed more often than men to sexual assault situations or family protection cases, units which do not effectively lead to promotion, Westmarland examines each unit in depth, including how the officers perceive their role in the unit and how officers perceive the opposite sex's role. For example, one female officer noted that male officers often shy away from child related cases, despite having children themselves. Female officers, even those with who do not have children, are assumed to have the skills necessary to handle the situation. Despite the long discussion of each gender-oriented unit, Westmarland found women frequently chose to specialize in these areas, a conclusion which often ran contradictory to the anecdotes shared by female officers. Westmarland concluded that due to how calls are prioritized and with the use of computer dispatching systems, differential deployment by gender was not an issue in either police force.

Notwithstanding the lackluster conclusion regarding differential deployment, Westmarland's book touches on several important gender themes, such as masculinity being imposed on police behavior and lack of female involvement in high status situations involving cars, guns, and horses. Additionally, she discusses the paradox of women working on sexual assault or family protection units specifically to develop skills for promotion, even though the rate of female advancement to high administration positions lags. Throughout the discourse on gender and promotion, Westmarland found that both male 
and female officers resent the fact that there is female resentment of marginalization to specific units. Female officers expressed feelings of being trapped in a sexist career dynamic, while male officers felt the nurturing stereotypes of women were discriminatory toward male officers who may have been interested in working on the unit. According to Westmarland, there was a constant gender divide of work assignments and roles: Male officers avoided working with the public, while female officers dealt with victims, and male officers handled pursuit and restraint of offenders, while female officers filled out paperwork. It may be argued, however, that this gender divide may not be a conscious division of labor; instead it may be a result of gender roles stemming from informal gender boundaries prevalent in the broader culture (Diamond, 2003).

Despite issues of topic jumping, lack of clear definitions, and areas of weak development, Wesmarland's book was a unique view into the culture of policing from a gendered perspective when it was originally released. She was able to obtain a "behind the blue curtain" look at the law enforcement brotherhood and provided the policing literature a glimpse into masculinity, femininity, and the profession of law enforcement. Although the original book was published over ten years ago, this release does not diminish the value of the work. However, Gender and Policing is no longer a unique gender-oriented book. Wesmarland's research on gender and policing is now strongest when combined with other works such as Miller's (1999) work on community policing, or Silvestri's (2003) on leadership in policing. By reading works such as these together, a more comprehensive view of the complexities of gender and law enforcement is provided, with each book providing a unique contribution to the holistic view. Gender and Policing not only provides a comparatively international view of gender and policing, it also provides a detailed discussion of how gender influences daily police activities such as officer assignments for arrests or roles within partners. As a result, Westmarland's book is still a strong addition to any curriculum focusing on gender and law enforcement, when combined with other key readings.

\section{References}

Diamond, D. (2003). Book review: Gender and policing: Sex, power, and police culture. Criminal Justice

Review, 28, 155-156.

Miller, S. (1999). Gender and community policing: Walking the talk. Boston, MA: Northeastern University Press.

Silvestri, M. (2003). Women in charge: Policing, gender and leadership. Oxford, England: Willan Publishing. 